\title{
Physiological and Morphological Behavior of Hymenaea stigonocarpa Seedlings Submitted to Phosphorus
}

\author{
Patrícia Oliveira da Silva ${ }^{1}$ (D) 0000-0003-2242-320X \\ Leandro Carlos ${ }^{1}$ (D) 0000-0003-1736-6079 \\ Paulo Eduardo Menezes-Silva ${ }^{1}$ (D) 0000-0002-8122-3489 \\ Andréia Mendes da $\operatorname{Costa}^{1}$ (D) 0000-0003-0395-6190 \\ Kássia de Paula Barbosa ${ }^{1}$ (D) 0000-0002-1836-2881
}

\begin{abstract}
In face of the global situation, a practice which has been gaining strength is producing seedlings for environmental restoration. Among the species that stand out for such activity is Hymenaea stigonocarpa. However, little is known about their nutritional requirements. The objective of this study was to evaluate the morphophysiological behavior of $H$. stigonocarpa seedlings submitted to phosphorus doses. The design was completely randomized with five doses $\left(0,100,200,300\right.$ and $\left.400 \mathrm{mg} \mathrm{dm}^{-3}\right)$ and four replicates. Physiological, morphological, biomass and phosphorus content analyses were performed. There was a difference for root mass ratio, leaf mass ratio, shoot mass ratio, leaf area and root area. The dose of $200 \mathrm{mg} \mathrm{dm}^{-3}$ is recommended for H. stigonocarpa seedlings.
\end{abstract}

Keywords: physiological parameters, initial growth, jatobá do cerrado, allometric reasons.

\section{INTRODUCTION AND OBJECTIVES}

Faced with the current global situation of deforestation, burning, release of greenhouse gases, dropping water levels and extreme temperatures, one practice which is gaining strength is to produce seedlings of species capable of promoting environmental restoration. At the same time, these species must be a food, medicinal, timber, ecological and also ornamental alternative, considering that implanting exotic species is not necessary for this restoration, since many native species have this capacity.

Among several native Cerrado species, Hymenaea stigonocarpa Mart. ex Hayne can be mentioned, being one representative of the Fabaceae botanical family and Caesalpinoideae subfamily, which has potential in recovering degraded areas (Silva et al., 2014). The species can be found in Bolivia and Brazil, where the species occurs in the Amazon, Caatinga, Cerrado and the Pantanal. The species is popularly known as Jatobá do cerrado, and its pulp is used to prepare cakes, breads, cookies, ice cream and cereals (Silva et al., 2001). The methanolic extract from its fruit peels has antidiarrheal, gastroprotective, healing (Orsi et al., 2012), bronchitis, prostate cancer, pain, flu and cough alleviation/prevention properties (Bieski et al., 2012). In addition, the wood has good quality and is regionally used in fences, beams, poles, furniture and floors. Resins removed from the bark trunk are considered some of the best copals (viscous resins) used in the varnish industry. The bark can still be used to make canoes (Oliveira, 2011).

According to Soares et al. (2013), H. stigonocarpa is a typical species of acid soils and is not very demanding for nutrients to develop. Even considering that native Cerrado plants are adapted to low fertility soils, experimental fertilization studies indicate that woody species may respond to soil fertilization, especially when these nutrients are nitrogen and phosphorus (Scholz et al., 2007), since these are the most limiting nutrients for plant growth and development (Souza et al., 2014), acting in several important processes for the survival and growth of plants. For example, phosphorus acts in most metabolic processes of enzymes and participates in cell division, photosynthesis, and respiration (Shabnam \& Iqbal, 2016).

\footnotetext{
${ }^{1}$ Instituto Federal Goiano (IF Goiano), Rio Verde, GO, Brasil
} 
Alves et al. (2015) state that slow growing species such as $H$. stigonocarpa are more adapted to soils with a restricted supply of nutrients and less responsive to their supply. However, in a study of nitrogen, phosphorus and potassium suppression in another species of jatobá (H. courbaril L.), Nascimento et al. (2014) found that even though it is a climatic species (Oliveira et al., 2011) just as H. stigonocarpa, H. courbaril had its development limited by the lack of these nutrients. Thus, little is known/found when searching the literature for information on the nutritional requirements of this species in the molting phase, and there are controversies on the subject (Soares et al., 2013).

Considering this, studies carried out in pots which evaluate the initial growth of native plants are necessary so that they not only analyze biometric or nutritional variables, but also the greatest number of possible variables to understand to what level phosphate fertilization can influence seedling formation of native species. Thus, the objective of this study was to assess the physiological and morphological behavior of H. stigonocarpa seedlings submitted to different phosphorus doses in a greenhouse and in a Dystrophic Red Latosol.

\section{MATERIALS AND METHODS}

The experiment was conducted at the Goiano Federal Institute, Rio Verde Campus, Brazil, under greenhouse conditions. The soil used in the study was classified as Dystrophic Red Latosol (Embrapa, 2013). Samples from five different points of the $0-20 \mathrm{~cm}$ soil layer were collected to analyze chemical composition (Embrapa, 2009). The chemical analyzes were performed according to the following methods: $\mathrm{pH}\left(\mathrm{H}_{2} \mathrm{O}-\right.$ Ratio 1:2.5); organic matter (Walkley \& Black method); $\mathrm{P}$ and $\mathrm{K}$ $\left(\mathrm{HCl} 0.05\right.$ molc L $^{-1}+\mathrm{H}_{2} \mathrm{SO}_{4} 0.025$ molc L$\left.^{-1}\right) ; \mathrm{Ca} \mathrm{Mg}$, $\mathrm{Al}$ and $\mathrm{H}+$ $\mathrm{Al}$ (KCl $1 \mathrm{molc} \mathrm{L}^{-1}$ extractor) according to Embrapa (2009). The chemical characterization of the soil under natural conditions is described in Table 1.
A physical analysis was performed to determine the particle size of the air dried soil according to the pipette method. The soil under natural conditions presented the following concentrations of clay, sand and silt: 500, 320 and $180 \mathrm{~g} \mathrm{~kg}^{-1}$, respectively. The soil description already prepared for conducting the experiment (liming and basic fertilization) is also presented in Table 1.

The calculation of the soil correction followed the methodology proposed by Raij (1981) to raise the base saturation to $60 \%$ for all pots. The correctives used were calcium carbonate and magnesium carbonate in the ratio of 4:1 (Freitas et al., 2017), individually incorporated into the pots. The seeds were submitted to manual scarification in the region opposite to the hilum and immersed in distilled water according to the Santos et al. (2011) methodology, then seeded in pots. The pot soil was maintained at $60 \%$ of field capacity according to the International Association of Engineering Geology (IAEG, 1979).

The phosphorus experiment consisted of five doses, four replicates, totaling 20 experimental units, and the experimental design was completely randomized. The treatments were: control (soil in natural condition), 100, 200,300 and $400 \mathrm{mg} \mathrm{dm}^{-3}$ (adapted from Leite et al., 2012), using monoammonium phosphate as the phosphorus source and urea and ammonium sulfate for balancing the nitrogen. The basic fertilization consisted of $100 \mathrm{mg}$ of ammonium sulfate, $110 \mathrm{mg}$ of potassium chloride, $58 \mathrm{mg}$ of copper sulphate, $81 \mathrm{mg}$ of boric acid and $173 \mathrm{mg}$ of zinc sulphate per pot, all applied as a solution.

The morphological evaluations were performed in all seedlings and consisted of plant height and collector diameter, obtained with a millimetered ruler and digital caliper, respectively, taking the terminal bud (apical meristem) as the standard (Delarmelina et al., 2014). In addition to these measurements, the total number of expanded leaves, number of main shoot internodes and branch lengths were also counted by a millimeter ruler. The relative growth rate for height, diameter and length of the branches were subsequently calculated according to Benincasa (2003).

Table 1. Chemical characterization of Dystrophic Red Oxisol at 0-20 cm depth in natural conditions and with basic fertilization, liming and treatments.

\begin{tabular}{|c|c|c|c|c|c|c|c|c|c|}
\hline \multirow{2}{*}{ Treatment } & \multirow{2}{*}{$\mathbf{P h}$} & $\mathrm{Al}^{3+}$ & $\mathrm{Ca}$ & $\mathrm{Mg}$ & $\mathrm{H}+\mathrm{Al}^{3+}$ & $\mathbf{P}$ & $\mathbf{K}$ & \multirow{2}{*}{$\begin{array}{c}\mathrm{OM} \\
\mathrm{g} / \mathrm{kg}\end{array}$} & \multirow{2}{*}{$\frac{\mathrm{V}}{\%}$} \\
\hline & & \multicolumn{4}{|c|}{$\mathrm{cmol}_{\mathrm{c}} \mathrm{dm}^{-3}$} & \multicolumn{2}{|c|}{$\mathrm{mg} \mathrm{dm}^{-3}$} & & \\
\hline Natural & 4.3 & 0.3 & 0.4 & 0.1 & 4.5 & 1 & 100 & 2.7 & 12 \\
\hline P0 & 5.4 & 0.1 & 3.4 & 1.5 & 4.9 & 2.1 & 160 & 3.4 & 52 \\
\hline P100 & 5.2 & 0.1 & 2.9 & 1.3 & 2.9 & 9.7 & 146 & 3.8 & 61 \\
\hline P200 & 5.3 & 0.1 & 3.1 & 1.3 & 4.5 & 10.4 & 143 & 3.6 & 52 \\
\hline P300 & 5.2 & 0.1 & 3.2 & 1.4 & 4.8 & 22.4 & 160 & 3.8 & 51 \\
\hline P400 & 5.1 & 0.1 & 3.2 & 1.4 & 4.2 & 52.4 & 156 & 3.9 & 55 \\
\hline
\end{tabular}

pH: hydrogen potential; $\mathrm{Al}^{3}$ : aluminum; Ca: calcium; $\mathrm{Mg}$ : magnesium; $\mathrm{H}+\mathrm{Al}$ : hydrogen plus aluminum; $\mathrm{P}$ : phosphorus; $\mathrm{K}$ : potassium; OM: organic matter; V: base saturation. Phosphorus doses (P0, P100, P200, P300 and P400 $\mathrm{mg} \mathrm{dm}^{-3}$ ). 
Photosynthetic pigment analyzes were performed by determining the Falker Chlorophyll Index ( $\mathrm{a}$ and $\mathrm{b}$ ) on one leaf. To do so, Clorofilog equipment (Model CFL1030, Falker Agricultural Automation, Porto Alegre, BR) was used. The chlorophyll a/b ratio was subsequently calculated, as well as the total chlorophyll index (chlorophyll a + chlorophyll b).

The physiological analyses consisted of: photosynthetic rate $\left[\mu \mathrm{mol}\left(\mathrm{CO}_{2}\right) \mathrm{m}^{-2} \mathrm{~s}^{-1}\right]$ and transpiration $\left[\mathrm{mmol}\left(\mathrm{H}_{2} \mathrm{O}\right) \mathrm{m}^{-2} \mathrm{~s}^{-1}\right]$, stomatal conductance $\left[\mathrm{mol}\left(\mathrm{H}_{2} \mathrm{O}\right) \mathrm{m}^{-2} \mathrm{~s}^{-1}\right]$, instantaneous carboxylation efficiency, relationship between internal and external $\mathrm{CO}_{2}$ concentration, photochemical quenching, electron transport rate and effective fluorescence. These evaluations were performed using an infrared gas analyzer (Model Li-6400XT, Li-Cor, Nebraska, USA), with photon flux density at 1,000 $\mu \mathrm{mol}$ $\mathrm{m}^{-2} \mathrm{~s}^{-1}$. The analyses were performed on fully expanded leaves, one leaf per plant, between 8 and 11 a.m. in the morning.

The seedlings were removed from the pots, washed in distilled water and separated into shoot, leaves and roots. After separation of the vegetative organs, they were placed in Kraft paper bags with the treatment identification and put into a circulation air oven at $65^{\circ} \mathrm{C}$ until obtaining constant mass (Freiberger et al., 2013). The leaf dry mass, shoot dry mass, root dry mass and total dry mass were subsequently obtained (Delarmelina et al., 2014). Next, the following elements were calculated: leaf mass ratio (leaf dry matter/total dry matter, $\mathrm{gg}^{-1}$ ), shoot mass ratio (shoot dry matter/total dry matter, $\mathrm{gg}^{-1}$ ), root mass ratio (root dry matter/total dry matter, $\mathrm{gg}^{-1}$ ), following the methodology by Fialho et al. (2011) and shoot over root.

The leaf area was determined before the seedlings were taken to the greenhouse. To do so, photographic records of the leaves of each experimental unit were taken using white paperboard. Image J Software (Research Services Branch, National Institute of Mental Health, Bethesda, Maryland, USA) was subsequently used to calculate leaf area.
The specific leaf area (SLA) was calculated with leaf area and leaf dry mass data according to the formula proposed by Barbieri et al. (2007): SLA = LA/LDM, where LA corresponds to leaf area and LDM to the leaf dry mass.

The leaves, shoots and roots of the H. stigonocarpa seedlings were ground in a Wiley mill $(2 \mathrm{~mm}$ mesh) to determine the phosphorus content after being dried in the greenhouse and weighed to determine biomass. Then $0.5 \mathrm{~g}$ of each sample was calcined in muffle furnace and then read on a spectrophotometer (Embrapa, 2009).

The obtained data were submitted to analysis of variance and applied to regression analysis at 0.05 significance level of probability using the Sisvar 5.3 statistical program (Ferreira, 2011).

\section{RESULTS}

The seedling height decreased as a function of the phosphate doses, with the highest value found using a dose of $10.8 \mathrm{mg} \mathrm{dm}^{-3}$ of phosphorus; on the other hand, the shoot growth rate increased linearly with the dose of $400 \mathrm{mg} \mathrm{dm}^{-3}$ promoting the greatest effect (Figure 1a and e).

The effect for the diameter, number of leaves and internodes was quadratic and the maximum obtained response was 330,220 and $125 \mathrm{mg} \mathrm{dm}^{-3}$ of phosphorus, respectively (Figure $1 \mathrm{~b}, \mathrm{c}$ and $\mathrm{d}$ ).

The phosphorus doses with the best responses for leaf dry mass, shoot dry mass, shoot mass ratio, root dry mass, total dry mass, specific leaf area and leaf area were 167, 216, 400, $119,155,330$ and $200 \mathrm{mg} \mathrm{dm}^{-3}$, respectively (Figure 2a, c, d, $e, g, h$ and $j)$. The best fit equation for leaf mass ratio, root mass ratio, and shoot over root was linear (Figure $2 b, f$ and $i$ ). Among these variables, phosphorus treatments showed a significant difference at $0.05 \%$ probability for leaf mass ratio, shoot mass ratio, shoot dry mass, shoot over root and leaf area of the H. stigonocarpa seedlings.

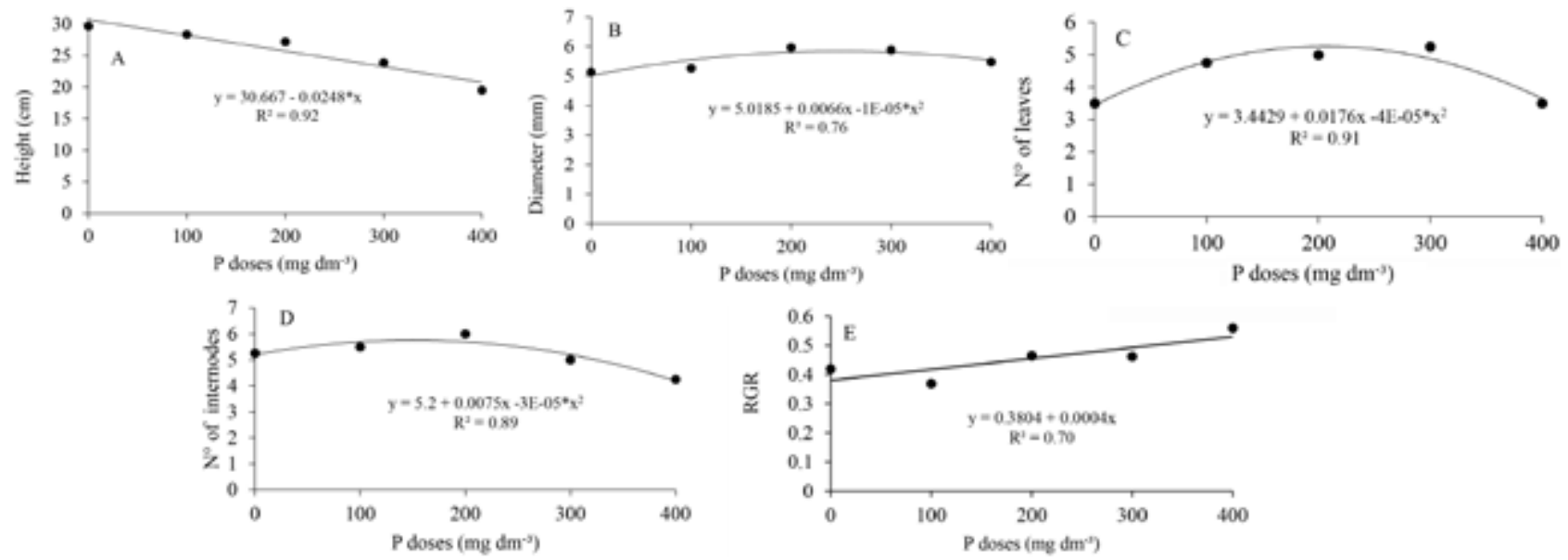

Figure 1. Morphological variables of $H$. stigonocarpa at 270 days after planting. A-Height, B-Diameter, C-Number of leaves, D-Number of internodes, E-Relative stem growth rate (RGR). 
The quadratic equation was the one that better fit the obtained data for the Falker Chlorophyll Index and total chlorophyll (Figure $3 \mathrm{a}$ and $\mathrm{b}$, respectively), with the highest effective doses
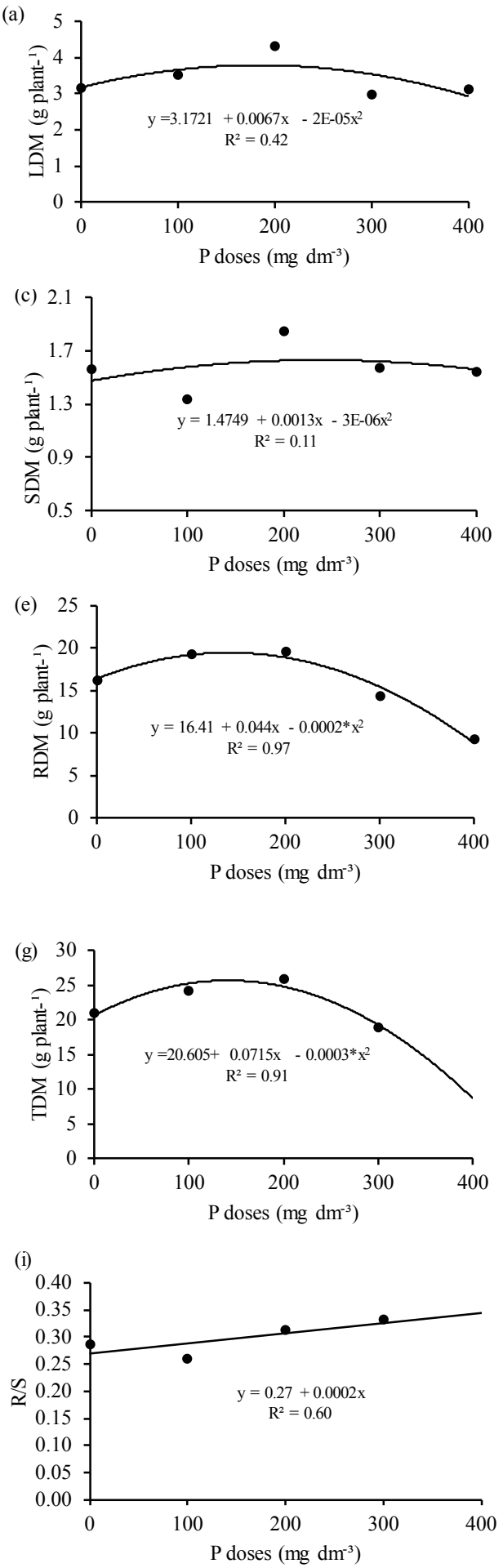

being 124.3 and $122.4 \mathrm{mg} \mathrm{dm}^{-3}$, while the most effective dose for the chlorophyll a/b ratio was $83.3 \mathrm{mg} \mathrm{dm}^{-3}$ phosphorus (Figure $3 c)$. The data for the chlorophyll b index were not satisfactory.
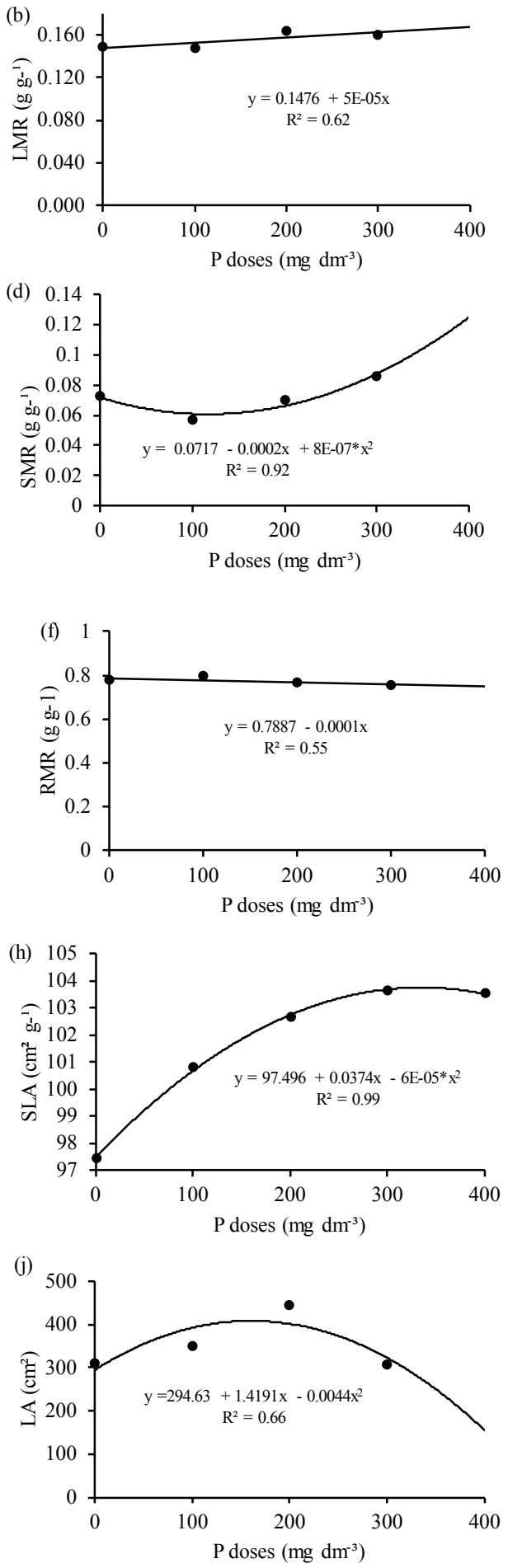

Figure 2. Biomass of H. stigonocarpa seedlings at 270 days after planting. A-Leaf dry mass (LDM), B-Leaf mass ratio (LMR), C-Shoot dry mass (SDM), D-Shoot mass ratio (SMR), E- Root dry mass (RDM), F-Root mass ratio (RMR), G-Total dry mass (TDM) and H-Specific leaf area (SLA), I-Shoot over root (S/R) and J-leaf area (LA). 

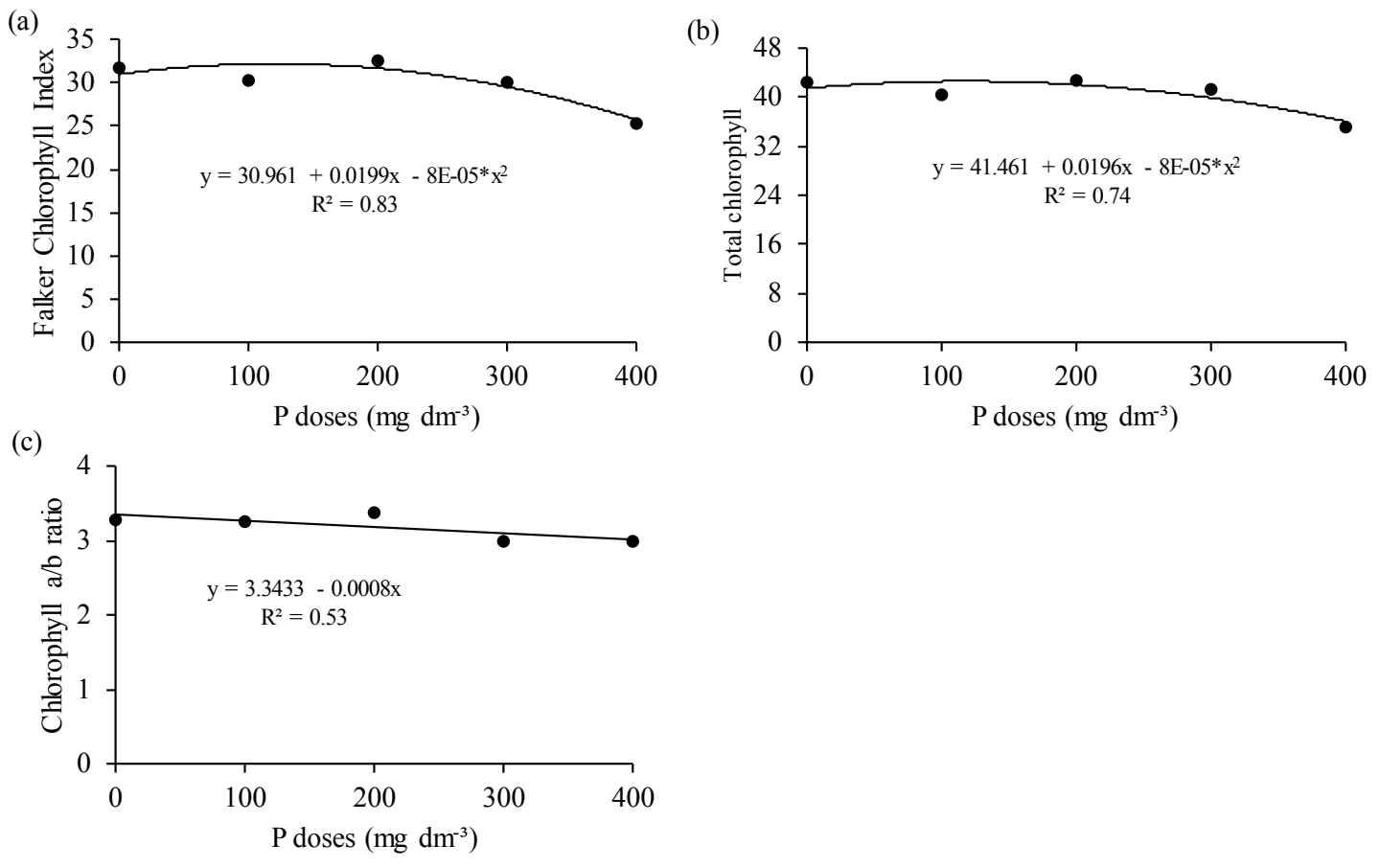

Figure 3. Falker Chlorophyll Indices in H. stigonocarpa seedlings.
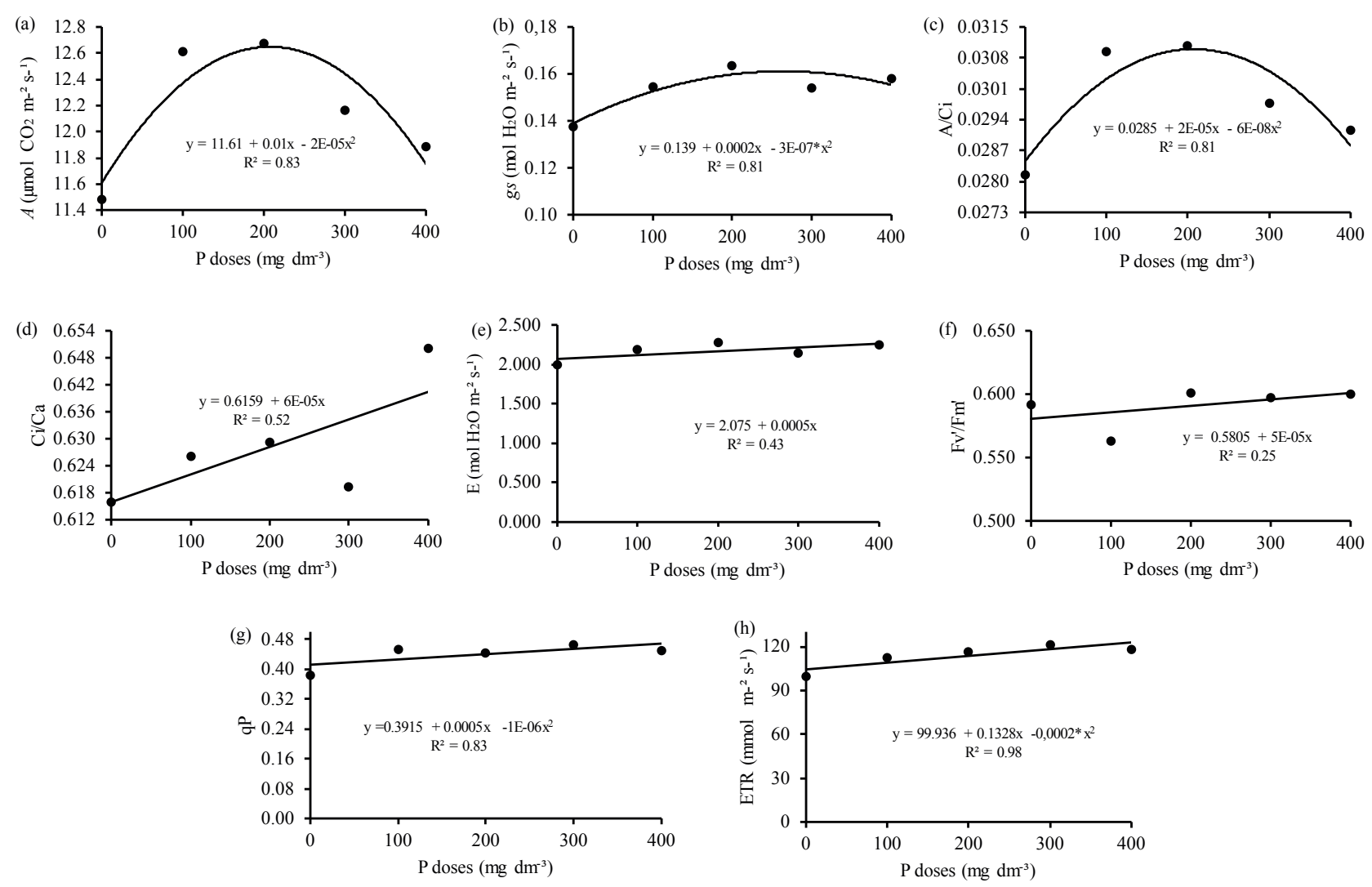

Figure 4. Physiological analyses of H. stigonocarpa. A-Photosynthetic rate $(A)$, B-Stomatal conductance $(g s)$, C-Instantaneous Efficiency of Carboxylation $(\mathrm{A} / \mathrm{Ci})$, D-relation between internal and external $\mathrm{CO}_{2}$ concentration $(\mathrm{Ci} / \mathrm{Ca})$, E-Transpiratory rate (E), F-Excitation energy capture efficiency by the reaction centers Open PSII (Fv'/Fm'), G-Quentinch photochemical $\left({ }_{\mathrm{Q}} \mathrm{P}\right)$ and H-Electron transport rate (ETR). 
The phosphorus doses that promoted the highest values of the liquid photosynthesis, stomatal conductance and instantaneous carboxylation efficiency variables were $250 \mathrm{mg} \mathrm{dm}^{-3}$ for both photosynthetic rate and stomatal conductance, and $166.6 \mathrm{mg} \mathrm{dm}^{-3}$ for the ratio between photosynthesis and internal concentration (Figure $4 \mathrm{a}, \mathrm{b}$ and c). The best fit equation for the obtained data was linear for the internal and external $\mathrm{CO}_{2}$ concentration, transpiration rate and potential quantum yield of photosystem II, photochemical quenching and electron transport rate variables (Figure $4 \mathrm{~g}$ and $\mathrm{h}$, respectively), with the higher doses in the study promoting the greatest effects.

The equations of the phosphorus content for leaf, shoot and root in the H. stigonocarpa seedlings conformed to a quadratic model (Figure 5).

The maximum response found for the phosphorus content in the leaves was $175 \mathrm{mg} \mathrm{dm}^{-3}$ (Figure 5a), while the dose of $290 \mathrm{mg} \mathrm{dm}^{-3}$ was found for the stem (Figure $5 \mathrm{~b}$ ), and $250 \mathrm{mg} \mathrm{dm}^{-3}$ for the root (Figure $5 \mathrm{c}$ ).

\section{DISCUSSION}

The results obtained in this study reveal that although $H$. stigonocarpa is a sensitive species to nutritional variation, it is not very responsive to phosphate fertilization; these results are in accordance with the research by Soares et al.
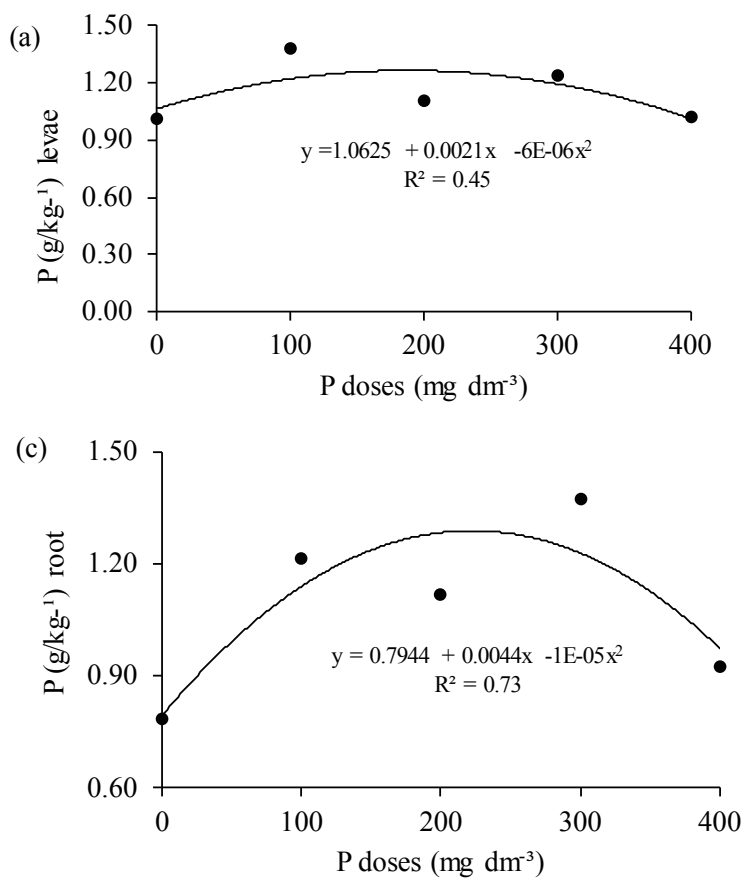

(2013) and Alves et al. (2015), as the treatments influenced few variables. However, this characteristic is not exclusive to the studied species, but also to species belonging to the successional climax group. When evaluating the behavior of forest species from different successional groups also due to adding increased doses of phosphorus, Santos et al. (2008) verified that the climatic species such as guanandi (Calophyllum brasiliensis Camb.) and oil-balsam (Myroxylon peruiferum L. f.) had practically no change in growth due to the increase in phosphorus doses.

However, some species may develop mechanisms to circumvent the need for phosphate fertilization because they are species in nutrient poor environments, independently of the successional group to which they belong. Thus, pioneer species may also not respond to phosphate fertilization, as in the case of pequi (Caryocar brasiliense Camb.) (Carlos et al., 2014) and Brazilian mahogany (Swietenia macrophylla King) (Tucci et al., 2011), typical species of the Cerrado and Amazon, respectively, with both having seeds considered large, as well as $H$. stigonocarpa. This suggests that the fact that some Cerrado species do not have significant responses to fertilization may also be related to the fact that they present seeds with voluminous almonds with a reasonable nutrient content that can sufficiently supply the seedling formation phase (Carlos et al., 2014).

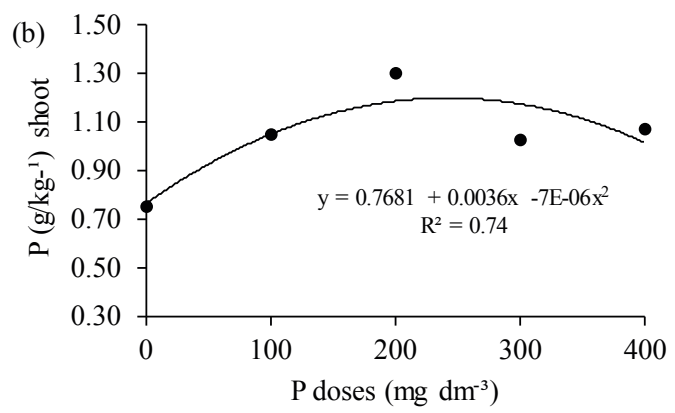

Figure 5. Phosphorus content in the tissue of $H$. stigonocarpa seedlings at 270 days after planting. A-Concentration of phosphorus in the leave, B-shoot and C-root. 
Among the morphological behavior of H. stigonocarpa seedlings, the most striking is the significant increase in phosphorus in the diameter of the seedlings, inversely to what occurred at that time. This may be due to the fact that the seedlings become more robust and vigorous, possibly to support the increase in the number of leaves and leaf area promoted by increasing phosphorus doses. Results similar to that of this study were also found in coffee (Coffea arabica L.) by Mera et al. (2011). Yamada et al. (2000) corroborate the data obtained when they affirm that some species tend to allocate biomass for the growth in stem thickness by having greater expansion in their photosynthetically active area (larger crown) in less illuminated microenvironments in order to increase the light absorption and thus the photosynthetic activity.

Species studied for being considered a climax, which means not very demanding for light, may be expressing its genetic characteristics programmed to grow and develop as if in the field. According to McMachon (1973), there is another explanation for this behavior; plants that invest less in height and more in diameter are strategically seeking sustenance, and this mainly occurs in environments with adverse environmental conditions like intense winds and inclined terrain, which would also partly explain this behavior since these events are not uncommon in Cerrado areas where the studied species is usually found. Thus, according to Souza et al. (2006), it is important to highlight that the stem diameter is very important to evaluate the seedling potential for survival and growth after planting.

The fact that increasing phosphorus doses did not promote a difference in chlorophyll indexes, even if there was an increase in doses in this study, is in agreement with Nascimento et al. (2014), who also found that phosphorus suppression did not promote a difference in chlorophyll concentrations in jatobá da mata (H. courbaril) seedlings, since nitrogen is the basic constituent nutrient of chlorophylls (Costa et al., 1988) and not phosphorus.

In physiological terms, the increase in leaf area promoted by increasing phosphorus doses also increased the stomatal conductance of the H. stigonocarpa seedlings, which results in a greater influx of $\mathrm{CO}_{2}$ and consequently a higher photosynthetic rate, requiring the increase of water, meaning greater perspiration. All this is because the increase in the phosphorus doses allowed a greater proportion of the light to be absorbed by the chlorophylls in photosystem II (PSII) to be directed to the photochemical stage. In addition, the increase in excitation energy capture efficiency by the PSII open reaction centers and the high electron carrier rates also tended to increase, which leads to increased NADPH and ATP production (Taiz \& Zeiger, 2014) and consequently greater photosynthesis, higher carbon fixation and biomass investment, as observed for several variables studied herein, although did not express statistical difference between treatments.

Among the evaluated biomass variables, the leaf, shoot and root biomasses tend to decrease when submitted to higher phosphorus doses, but this decrease was more significant in the root biomass. According to Marschner (1996), root growth is mainly favored in nutrient deficient soils, notably in nitrogen and phosphorus, as a strategy to increase the search and absorption area to extract the maximum of nutrients present in the soil (Fernandes et al., 2000). Thus, H. stigonocarpa seedlings submitted to the highest phosphorus doses would have no reason to continue investing in root biomass to increase their absorption area, since the necessary or even sufficient amount is being offered through fertilization. Thus, there is no need to increase root biomass under such conditions, leading the seedlings to direct their biomass investment to the shoot. This biomass redirection promoted the already mentioned gains, such as increase in stem growth rate, diameter, number of leaves and leaf area.

The leaf area expresses the effect of leaf emergence and expansion, interaction with $\mathrm{CO}_{2}$ input and energy flow, directly affecting the interception of solar radiation, photosynthesis, biomass accumulation, transpiration and gas exchange (Kandiannan et al., 2009). Therefore, a significant increase in the leaf area of $H$. stigonocarpa seedlings by increasing phosphorus doses led to an increase in the ability of the seedlings to capture solar energy to raise their photosynthetic rate and consequently the shoot biomass gain. In other studies, phosphate fertilization also promoted gains in the leaf area, as in the case of jatropha (Jatropha curcas L.) (Lima et al., 2011) and coffee (C. arabica L.) (Mera et al., 2011).

The fact that the phosphorus content was higher in the lower doses and lower in the higher doses for the H. stigonocarpa seedlings may be associated to the fact that both the excess and the phosphorus deficiency can negatively affect the growth rate of the plants. Part of this nutrient is exported to the shoot when high phosphorus concentration conditions exist in the root, and phosporus absorption by the root system is reduced when in sufficient concentrations to satisfy the needs of the plant (Magadlela et al., 2014). In addition, high phosphorus concentrations can inhibit the absorption of other necessary nutrients for the growth and development of plants.

\section{CONCLUSIONS}

Phosphate fertilization promoted positive variations in the physiological and morphological behavior of $H$. stigonocarpa seedlings, so that more robust and vigorous seedlings were observed. Thus, the recommended dose for producing $H$. stigonocarpa seedlings in Dystrophic Red Latosol is $200 \mathrm{mg} \mathrm{dm}^{-3}$ of phosphorus. 


\section{ACKNOWLEDGEMENTS}

Instituto Federal Goiano, Campus Rio Verde (IF Goiano-Rio Verde) and Coordenação de Aperfeiçoamento de Pessoal de Nível Superior (Capes).

\section{SUBMISSION STATUS}

Received: 8 Sept. 2017

Accepted: 23 Apr. 2019

\section{CORRESPONDENCE TO Patrícia Oliveira da Silva}

Instituto Federal Goiano (IF-Goiano), Rodovia Sul Goiana, km 1, CP 66, CEP 74001-970, Rio Verde, GO, Brasil

e-mail: patyoliveira1919@hotmail.com

\section{FINANCIAL SUPPORT}

Instituto Federal Goiano, Campus Rio Verde (IF Goiano-Rio Verde) and Coordenação de Aperfeiçoamento de Pessoal de Nível Superior (Capes).

\section{REFERENCES}

Alves JDN, Souza FCA, Oliveira ML, Oliveira MCMA, Okumura RS. Fontes de fósforo no crescimento inicial de mudas de jatobá-do-cerrado (Hymenaea stigonocarpa Mart.). Nucleus 2015; 12(2): 299-308. 10.3738/1982.2278.1460

Barbieri D Jr, Braga LF, Roque CG, Sousa MP. Análise de crescimento de Hymenaea courbaril sob efeito da inoculação micorrizica e adubação fosfatada. Revista de Ciências Agroambientais 2007; 5(1): 1-15.

Benincasa MMP. Análise de crescimento de plantas: noções básicas. Jaboticabal: Funep; 2003.

Bieski IGC, Santo FR, Oliveira RM, Espinosa MM, Macedo M, Albuquerque UP et al. Ethnopharmacology of medicinal plants of the Pantanal region (Mato Grosso, Brazil). Evidence-Based Complementary and Alternative Medicine 2012; 2012(1): 1-36. 10.1155/2012/272749

Carlos L, Venturin N, Macedo RLG, Higashika WAEM, Garcia $\mathrm{MB}$, Farias ES. Crescimento e nutrição mineral de mudas de pequi sob efeito da omissão de nutrientes. Ciência Florestal 2014; 24(1): 13-21. 10.5902/1980509813318

Costa RCL, Lopes NF, Oliva MA, Barros F. Efeito da água e do nitrogênio sobre a fotossíntese, respiração e resistência estomática em Phaseolus vulgaris. Pesquisa Agropecuária Brasileira 1988; 23(12): 1371-1379.

Delarmelina WM, Caldeira, MVW, Faria, JCT, Gonçalves, EO, Rocha, RLF. Diferentes substratos para a produção de mudas de Sesbania virgata. Floresta e Ambiente 2014; 21(2): 224-233. 10.4322/floram.2014.027

Empresa Brasileira de Pesquisa Agropecuária - Embrapa. Manual de análises químicas de solos, plantas e fertilizantes. 2nd ed. Brasília, DF: Embrapa; 2009.

Empresa Brasileira de Pesquisa Agropecuária - Embrapa. Sistema brasileiro de classificação de solos. 3rd ed. Brasília, DF: Embrapa; 2013.
Fernandes LA, Furtini Neto AE, Fonseca FC, Vale FR. Crescimento inicial, níveis críticos de fósforo e frações fosfatadas em espécies florestais. Pesquisa Agropecuária Brasileira 2000; 35(6): 1191-1198. 10.1590/S0100-204X2000000600016

Ferreira DF. Sisvar: a computer statistical analysis system. Ciência e Agrotecnologia 2011; 35(6): 1039-1042. 10.1590/S141370542011000600001

Fialho CMT, França AC, Tironi SP, Ronchi CP, Silva AA. Interferência de plantas daninhas sobre o crescimento inicial de Coffea arabica. Planta Daninha 2011; 29(1): 137-147. 10.1590/ S0100-83582011000100016

Freiberger MB, Guerrini IA, Galetti G, Fernandes DM, Corrêa JC. Crescimento inicial e nutrição de cedro (Cedrela fissilis Vell.) em função de doses de nitrogênio. Revista Árvore 2013; 37(3): 385-392. 10.1590/S0100-67622013000300001

Freitas ECS, Paiva HN, Leite HG, Oliveira Neto SN. Crescimento e qualidade de mudas de Cassia grandis Linnaeus F. em resposta à adubação fosfatada e calagem. Ciência Florestal 2017; 27(2): 509-519. $10.5902 / 1980509827732$

International Association for Engineering Geology - IAEG. Classification of rocks and soils for engineering geological mapping: part I: rock and soil materials. Bulletin of the International Association of Engineering Geology 1979; 19(1): 355-371. 10.1007/BF02600503

Kandiannan K, Parthasarathy U, Krishnamurthy KS, Thankamani KC, Srinivasan V. Modeling individual leaf area of ginger (Zingiber officinale Roscoe) using leaf length and width. Scientia Horticulturae 2009; 120(4): 532-537. 10.1016/j.scienta.2008.11.037

Leite GLD, Silva FWS, Guanabens RGM, Fernandes LA, Figueiredo LS, Silva LF. NPK and flavonoids affecting insect populations in Dimorphandra mollis seedlings. Acta Scientiarum: Agronomy 2012; 34(1): 17-22. 10.1590/S1807-86212012000100003

Lima RLS, Severino LS, Gheyi HR, Sofiatti V, Arriel NHC. Efeito da adubação fosfatada sobre o crescimento e teor de macronutrientes de mudas de pinhão manso. Revista Ciência Agronômica 2011; 42(4): 950-956. 10.1590/S1806-66902011000400017

Magadlela A, Kleinert A, Dreyer LL, Valentine AJ. Low-phosphorus conditions affect the nitrogen nutrition and associated carbon costs of two legume tree species from a Mediterranean-type ecosystem. Australian Journal of Botany 2014; 62(1): 1-9. 10.1071/BT13264

Marschner H. Mineral nutrient acquisition in nonmycorrhizal and mycorrhizal plants. Phyton 1996; 36(3): 61-68.

McMachon TA. Size and shape in biology. Science 1973; 179(4079): 1201-1204. 10.1126/science.179.4079.1201

Mera AC, Oliveira CAS, Guerra AF, Rodrigues GC. Regimes hídricos e doses de fósforo em cafeeiro. Bragantia 2011; 70(2): 2302-2311. 10.1590/S0006-87052011000200008

Nascimento HHC, Pacheco CM, Lima DRM, Silva EC, Nogueira RJMC. Aspectos ecofisiológicos de mudas de Hymenaea courbaril L. em resposta a supressão de N, P e K. Scientia Forestales 2014; 42(103): 315-328.

Oliveira DL. Viabilidade econômica de algumas espécies medicinais nativas do Cerrado. Estudos 2011; 38(2): 301-332. 10.18224/est.v38i2.2196

Oliveira WL, Medeiros MB, Moser P, Pinheiro R, Olsen LB. Regeneração e estrutura populacional de jatobá-da-mata (Hymenaea courbaril L.) em dois fragmentos com diferentes graus de 
perturbação antrópica. Acta Botanica Brasilica 2011; 25(4): 876-884. 10.1590/S0102-33062011000400014

Orsi PR, Bonamin F, Severi JA, Santos C, Vilegas W, Hiruma-Lima CA et al. Hymenaea stigonocarpa Mart. ex Hayne: a Brazilian medicinal plant with gastric and duodenal anti-ulcer and antidiarrheal effects in experimental rodent models. Journal of Ethnopharmacology 2012; 143(1): 81-90. 10.1016/j.jep.2012.06.001

Raij BV. Avaliação da fertilidade do solo. Piracicaba: Instituto da Potassa e Fosfato; 1981.

Santos JZL, Resende AV, Furtini Neto AE, Corte EF. Crescimento, acúmulo de fósforo e frações fosfatadas em mudas de sete espécies arbóreas nativas. Revista Árvore 2008; 32(5): 799-807. 10.1590/ S0100-67622008000500003

Santos LCR, Costa E, Leal PAM, Nardelli EMV, Souza GSA. Ambientes protegidos e substratos com doses de composto orgânico comercial e solo na formação de mudas de Jatobazeiro em Aquidauana-MS. Engenharia Agrícola 2011; 31(2): 249-259. 10.1590/S0100-69162011000200005

Scholz FG, Bucci SJ, Golstein G, Meinzer FC, Franco AC, MirallesWilhelm F. Removal of nutrient limitations by long-term fertilization decreases nocturnal water loss in savanna trees. Tree Physiology 2007; 27(4): 551-559. 10.1093/treephys/27.4.551

Shabnam R, Iqbal MT. Understanding phosphorus dynamics on wheat plant under split-root system in alkaline soil. Brazilian Journal of Science and Technology 2016; 3(1): 19. 10.1186/s40552-016-0031-6

Silva CP, Sousa MSB, Siguemoto ES, Soares RAM, Areas JAG. Chemical composition and antioxidant activity of jatobá-do-cerrado
(Hymenaea stigonocarpa Mart.) flour. Food Science and Technology 2014; 34(3): 597-603. 10.1590/1678-457x.6405

Silva MR, Silva MS, Martins KA, Borges S. Utilização tecnológica dos frutos de jatobá-do-cerrado e de jatobá-da-mata na elaboração de biscoitos fontes de fibra alimentar e isentos de açucares. Food Science and Technology 2001; 21(2): 176-182. 10.1590/S010120612001000200010

Soares JN, Reis JMR, Pereira IS, Reis MR, Gontijo RG. Avaliação do desenvolvimento de mudas de jatobá-do-cerrado (Hymenaea stigonocarpa Mart.) em diferentes fontes de fósforo. Cerrado Agrociências 2013; 13(4): 35-41.

Souza CAM, Oliveira RB, Martins Filho S, Lima JSS. Crescimento em campo de espécies florestais em diferentes condições de adubação. Ciência Florestal 2006; 16(3): 243-249.

Souza NH, Marchetti ME, Carnevali TO, Ramos DD, Scalon SPQ, Oliveira MT. Crescimento inicial de Stryphnodendron polyphylum (Mart.) em resposta à adubação com N e P. Cerne 2014; 20(3): 441-447. 10.1590/0104776020142003142

Taiz L, Zeiger E. Fisiologia vegetal. 5th ed. Porto Alegre: Artmed; 2014.

Tucci CAF, Santos JZL, Silva CH Jr, Souza PA, Batista IMP, Venturin $\mathrm{N}$. Desenvolvimento de mudas de Swietenia macrophylla em resposta a nitrogênio, fósforo e potássio. Floresta 2011; 41(3): 471-490. 10.5380/rf.v41i3.24039

Yamada T, Yamakura T, Lee HS. Architectural and allometric differences are related to microhabitat preferences. Functional Ecology 2000; 14(6): 731-737. 10.1046/j.1365-2435.2000.00479.x 